\title{
THE DESIGN OF FLOOD PROTECTION ALONG NAN RIVER, PHITSANULOK PROVINCE, THAILAND
}

\author{
Korakod NUSIT ${ }^{1}$, Sarintip TANTANEE ${ }^{2}$, Kumpon SUBSOMBOON ${ }^{3}$, Sasikorn \\ LEUNGVICHCHAROEN ${ }^{4}$, Suthat YIEMWATTANA
}

DOI: 10.21163/GT_2019.141.26

\begin{abstract}
:
Phitsanulok province is located in the northern region of Thailand, approximately $400 \mathrm{~km}$ away from Bangkok. One of its major river is Nan river, which runs thru the business district of Phitsanulok. Every year, Nan river severely erodes the riverbanks and damages the infrastructures located along the riversides. The river erosion also intimidates the inhabitants who live nearby the river. In the studied area, the ancient city walls have been discovered. These ancient city walls have continually been destroyed by the river erosions every year. Moreover, the area has been reported flooding every five to ten years. Accordingly, the mitigation system is required in the area to serve two main purposes. The first purpose is protecting the nearby communities from severe flooding and river erosions. Secondly, the mitigation system should provide comforts to the communities. The public hearing event was organized to gather the needs from the communities. As a result, the flexible sheet-pile wall was chosen as the flood protection and river erosion mitigation system in the area. The mitigation system was designed to harmonize with the ancient city walls and served as the recreation area for the communities.
\end{abstract}

Key-words: Ancient, Flexible Sheet-Pile Wall, Mitigation System, River Erosion, Urban Community.

\section{INTRODUCTION}

It is common for Thais to settle their community nearby the river. In ancient times, the river was the heart of Thais because it was the most convenient transportation route. The people in the community also need water for their daily usage. The rapid rate of population growth, especially in the city center, generally leads to the limitation of residential space. Therefore, the urban inhabitants are forced to establish their residents very close to the riversides. These inhabitants may be seriously disturbed by the flooding and river erosion events. It is understood that the river route is gradually changed by erosion, flooding, and other natural factors. However, the changes in river route also intimidate the urban communities. In Thailand, flooding events continually induce negative impacts to the communities and industries (Ministry of Finance, Royal Thai Government and The World Bank, 2012; Poaponsakorn \& Meethom, 2013; Ghaderi et al., 2014; Haragushi \& Lall, 2015). It is also reported that, as waterproofing the land in the cities, the water is no longer infiltrated, the drainage increases, resulting in increasing volumes of water that will raise

\footnotetext{
${ }^{1}$ Naresuan University, Department of Civil Engineering, Phitsanulok, Thailand, korakodn@nu.ac.th;

${ }^{2}$ Naresuan University, Center of Excellence on Energy Technology and Environment, Phitsanulok, Thailand, sarintipt@nu.ac.th;

${ }^{3}$ Naresuan University, Department of Civil Engineering, Phitsanulok, Thailand, kumpon@nu.ac.th;

${ }^{4}$ Naresuan University, Department of Civil Engineering, Phitsanulok, Thailand, sasikorn@nu.ac.th;

${ }^{5}$ Naresuan University, Department of Architecture, Phitsanulok, Thailand, suthaty@yahoo.com.
} 
the river flowing across the city (Haidu \& Ivan, 2016). On the other hand, the private assets and public infrastructures were reported to be damaged by flash flooding and river erosion events (Costache, 2014; Kabir et al., 2011).

Chao Phraya River is the most significant river of Thailand. It is the major river which conveys and distributes water to the agricultural areas located in the north and center of country (Chuenchooklin and Pangnakorn, 2015). The river is formed by the confluence of four rivers, which are; Ping, Wang, Yom, and Nan rivers. Phitsanulok is located approximately $400 \mathrm{~km}$ away from Bangkok, in the northern part of the country. Two important rivers flow through the Phitsanulok province. The Yom river enters the province in the north-western region from the Sukhothai province. On the other hand, the Nan river transports the water from the Nan province to Phitsanulok province via the Phare and Uttaradit provinces. The two rivers later join and form a single branch at the Pichit province, which located below the Phitsanulok province. In the centre district of the Phitsanulok province, the erosion of Nan river is one of the most anxious issues of the urban communities. The riverbank erosion causes the loss in private and public assets every flooding season. The municipality and community constantly work hard to control the flooding and river erosion along the Nan riverbank. Fig. 1 illustrates the aerial photo of the studied site in the past. The figure demonstrates the existence of public road before it collapsed by the river erosion. The Phutthabucha road appears in Fig. 1 was continually destroyed by the river erosion and flooding events. Fig. 2 shows the aerial photo of the studied site during the flooding event in 2011.

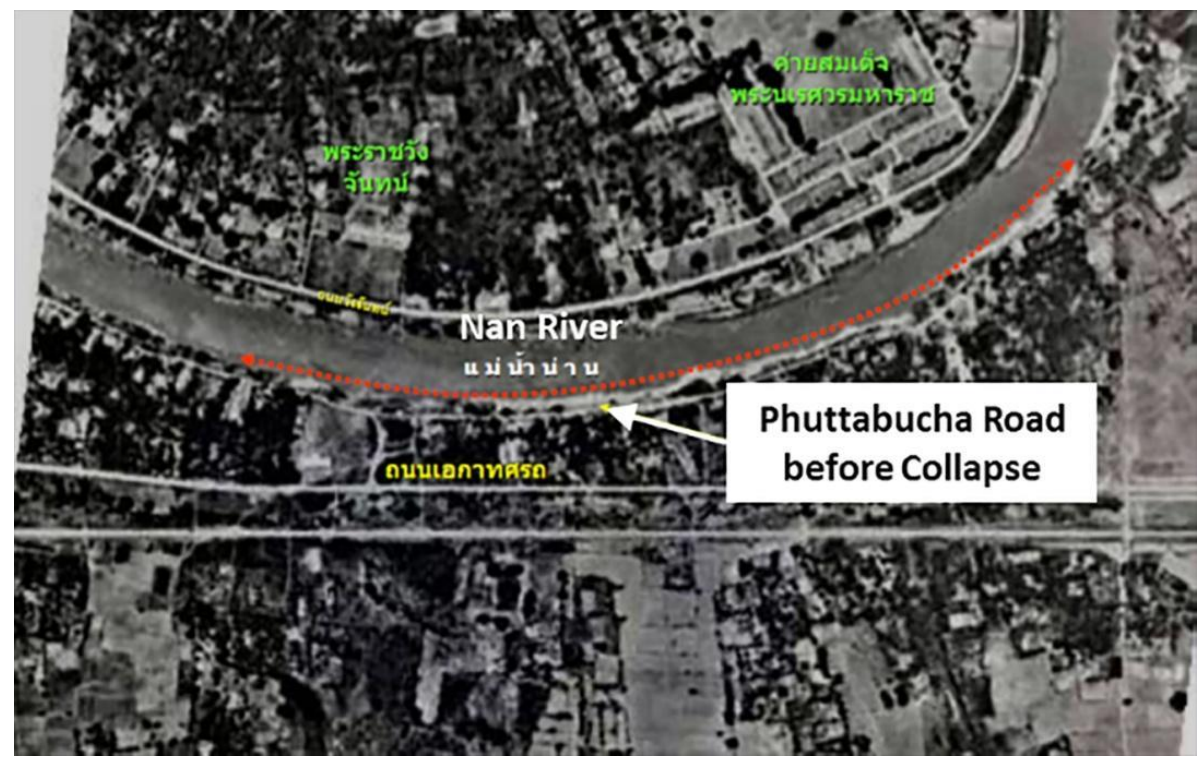

Fig. 1. Aerial photo of the studied site.

The flooding event in 2011 has brought concerns to the communities. Fig. 3 displays the consequences of river erosion and the flooding events along the riverbank. The ancient city walls along the riverbank were severely destroyed as shown in Fig. 3. The 500 year-old city walls with the embankment width of approximately $15 \mathrm{~m}$ were tremendously suffered from the flooding event in 2011. 


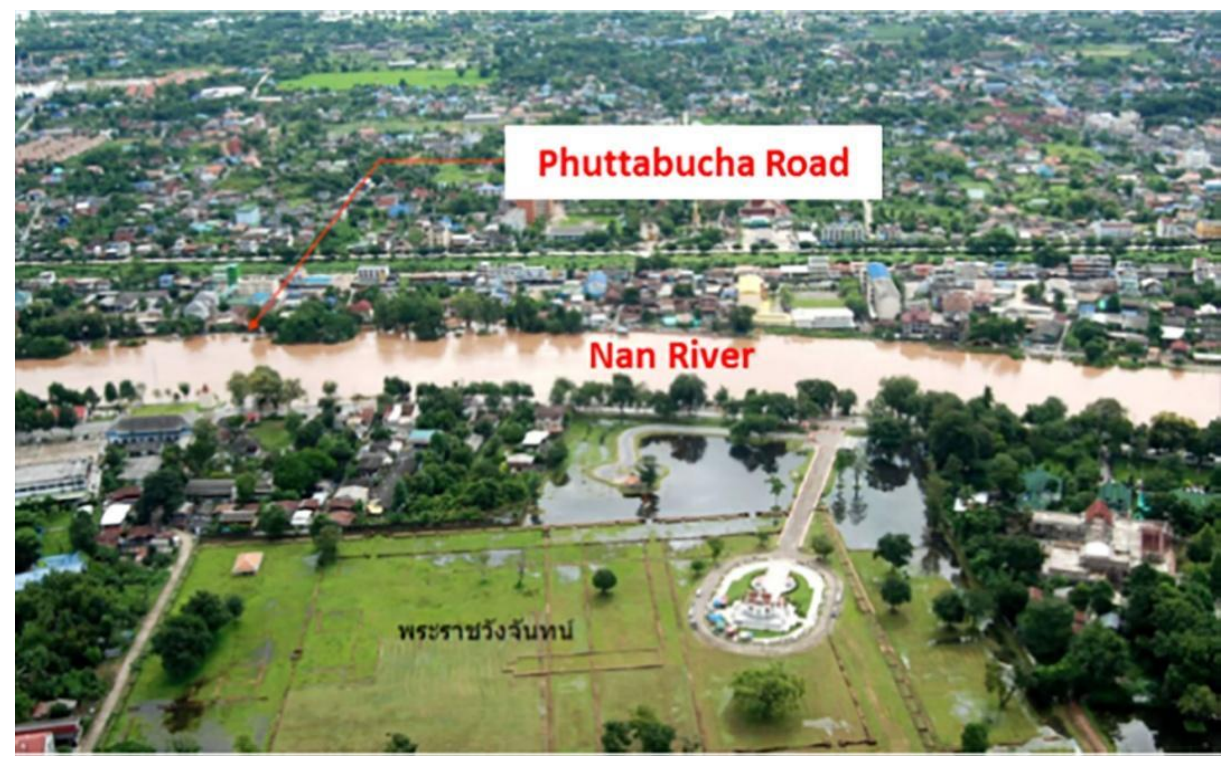

Fig. 2. The studied site in 2011.

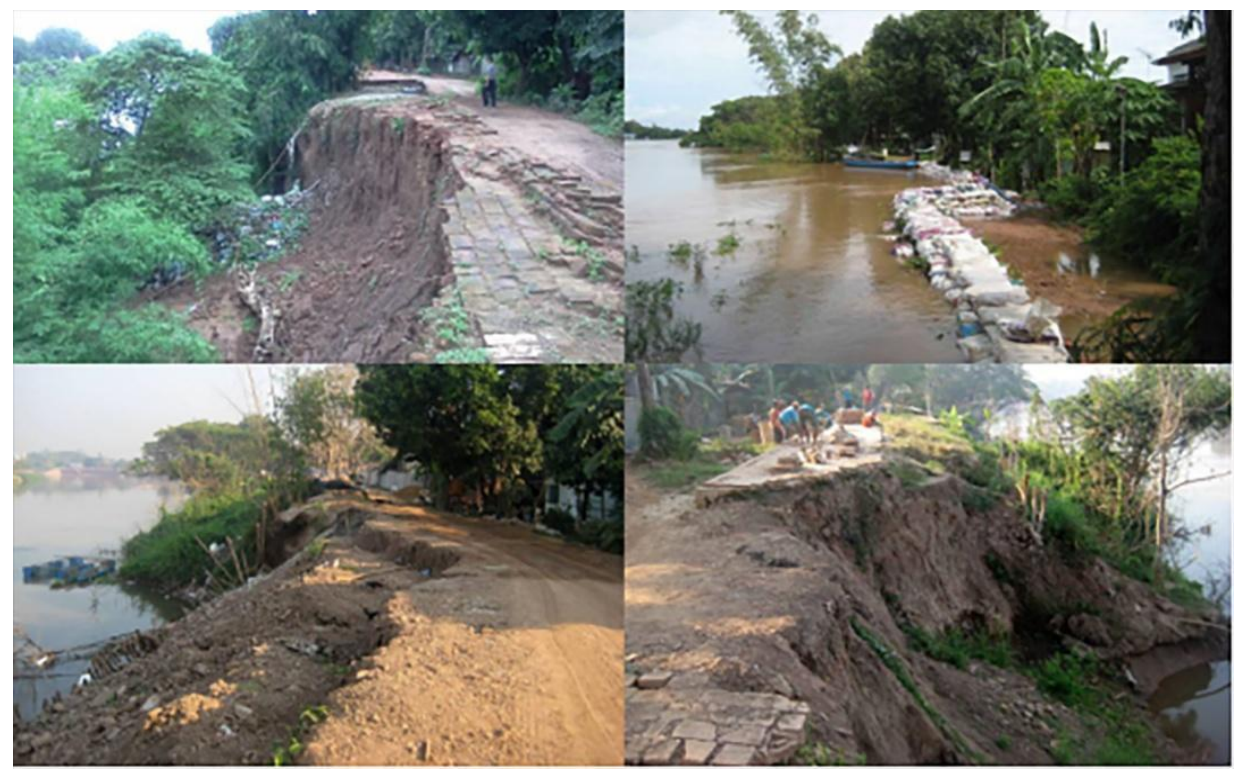

Fig. 3. Consequences from the river erosion and flooding event in 2011.

Accordingly, the mitigation system is urgently required in the area. This system should be able to mitigate the damages of future flooding events. Moreover, the system should be able to diminish the rate of river erosion along the riverbank. In addition, the mitigation system should be designed as the recreation area for the nearby communities. A careful and clear concept plan has to be designed and communicated well to the community vised for it to be accepted by the user (Gomis and Turón, 2017). 


\section{THE DEVELOPMENT OF MITIGATION SYSTEM AND CHALLENGES}

The main aim of the project is to provide the effective flood protection and river erosion mitigation systems to the Phuttabucha community. In the early stage of the project, the fundamental information for the mitigation system design was gathered. Fig. 4 illustrates the topographic map of the studied area. The soil investigation program was also conducted to collect the index and engineering properties of soil. The water level history was investigated and would be used for assigning the appropriate geometry of the mitigation system.

The topographic survey revealed that, the designed mitigation system would be built on the private estates. This is because the river has eroded the public road (Phuttabucha road) and continually damaged the private estates. Fig. 5 shows the designed flood protection and river erosion mitigation system over-laid by the map of private estate. It can be seen from Fig. 5 that the private estates are severely damaged by the river erosion and flooding events. These estates and the ancient city walls may be destroyed completely if the effective mitigation system is not implemented.

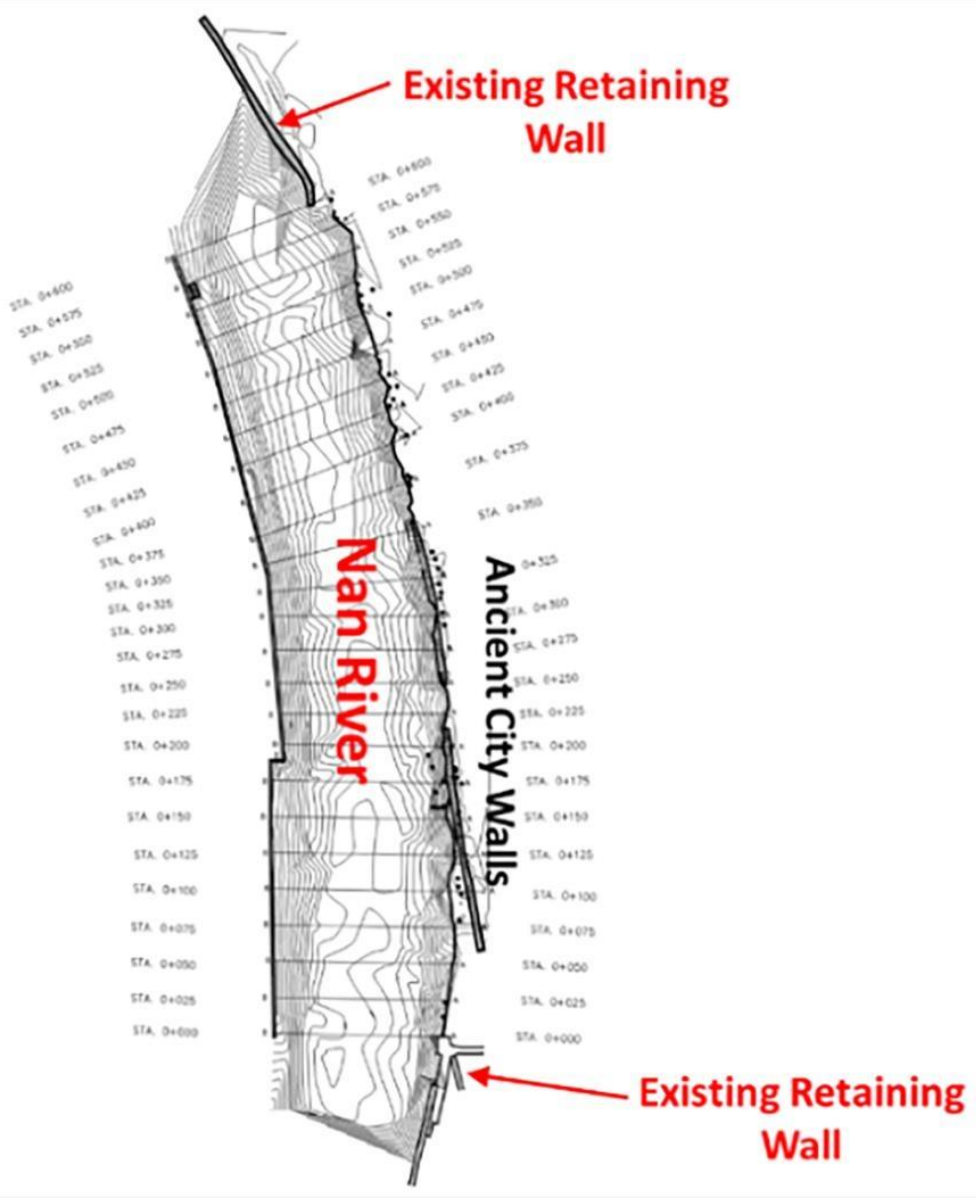

Fig. 4. Topographic map of the studied area. 


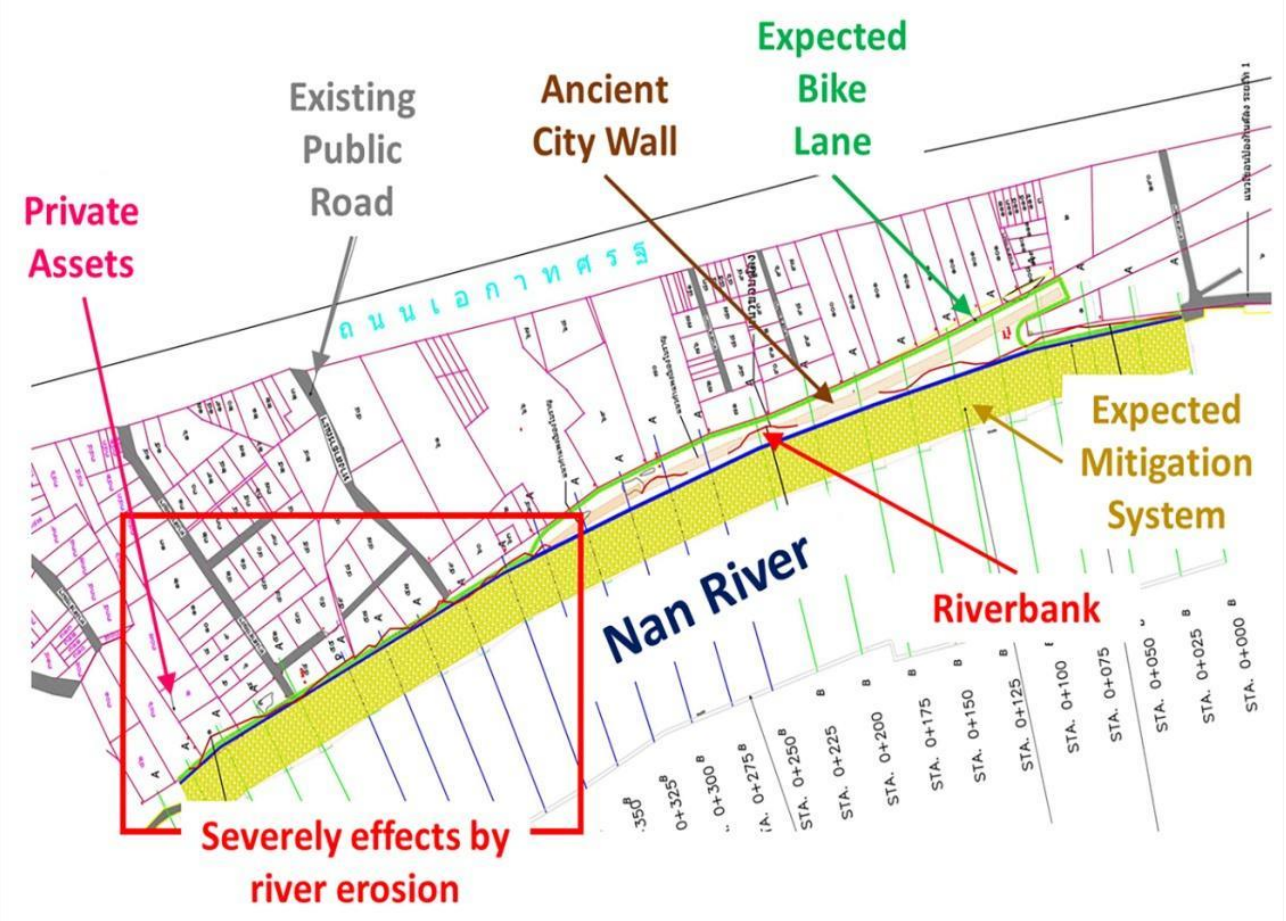

Fig. 5. The designed mitigation system over-laid by the private assets (in pink).

\section{DESIGN PROCEDURE}

The various schemes of mitigation system are available in the guideline developed by Department of Public Works and Town \& Country Planning (2006). To obtain the effective mitigation system, two alternative schemes of the mitigation system were preliminary designed based on the available information and field investigation results. These schemes were then presented to the communities and the stakeholders during the public hearing event. Accordingly, the effective and acquiesced mitigation system can be achieved at the end of the project.

\subsection{Alternative Schemes of Mitigation System}

The first alternative mitigation system is presented in Fig. 6. Four rows of Reinforced Concrete $(\mathrm{RC})$ pile were installed to prevent the global failure of soil slope along the riverbank. The river erosion is prevented by the rock rip-rap laid on the slope surface; while the retaining wall with $\mathrm{RC}$ plank was designed to protect the communities from flooding events.

Fig. 7 shows the second alternative mitigation system in the project. The global failure of soil slope along the riverbank is prevented by the continuous sheet-pile wall. The rock gabion was designed for controlling the river erosion in this 2 nd scheme. Rock gabion is a wire-mesh cage filled with rock (Bergado et al., 1996). Presently, the rock gabion is popularly used in Thailand for the river erosion control (Bergado \& Soralump, 2003) because the gabion is inexpensive and it can be installed easily on the slope face. 


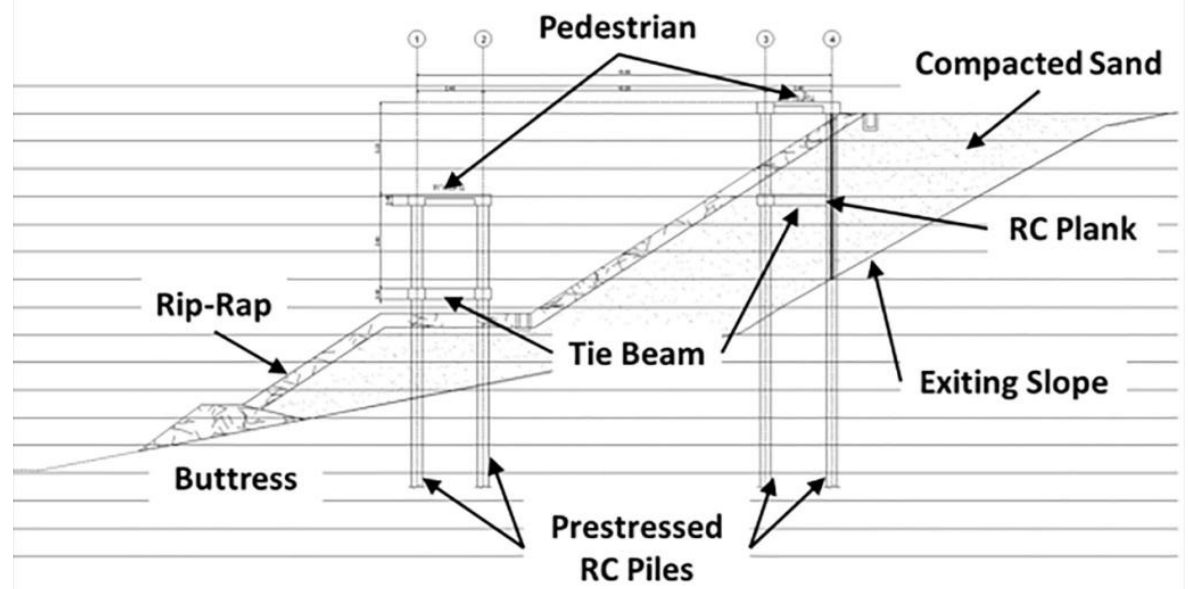

Fig. 6. First mitigation system.

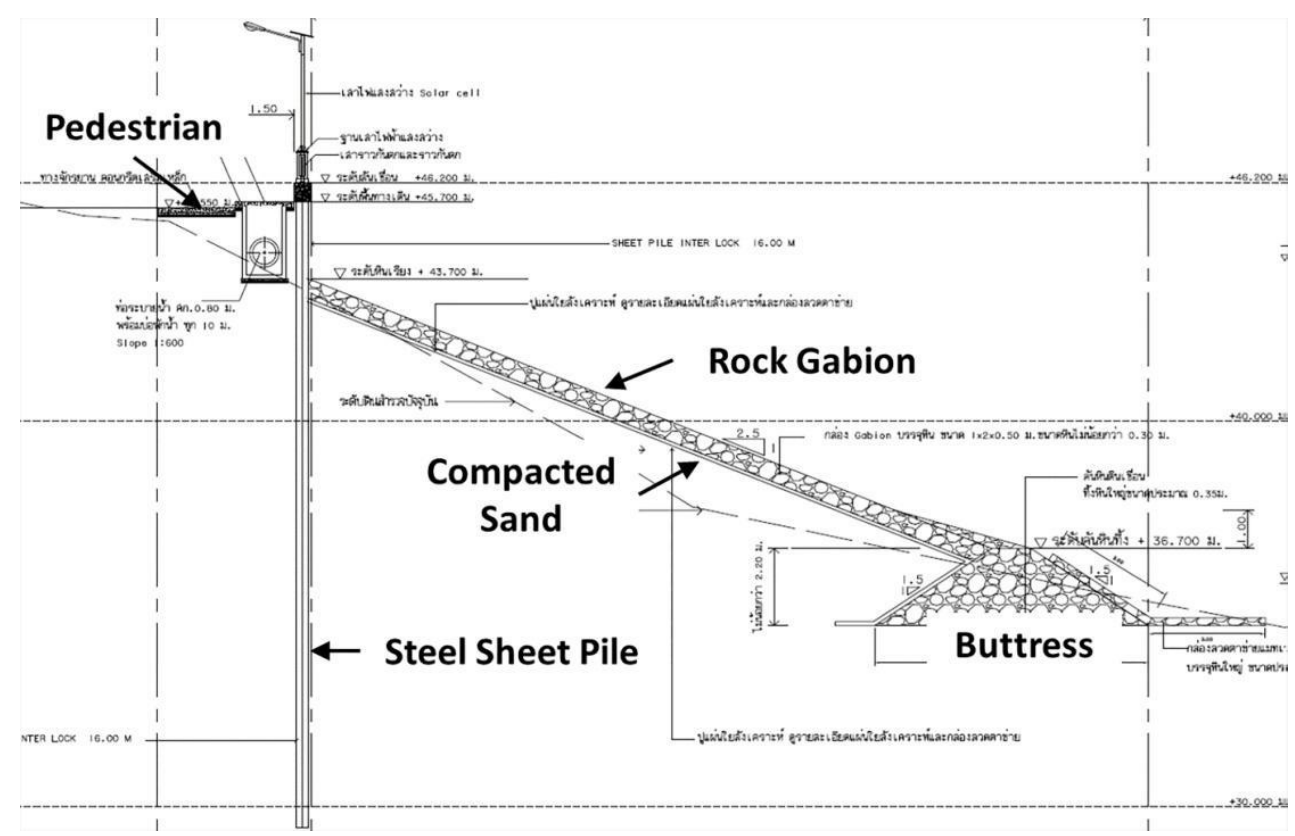

Fig. 7. Second mitigation system.

\subsection{Public Hearing Event}

The design team together with the municipality organized the public hearing event due to the public concerns mentioned previously. The total number of population in Phitsanulok municipality is 68,121 from 39,191 households (Phitsanulok Municipality, 2017). However, the participants of the public hearing event were the people who live in the expected construction area. Fig. 5 illustrates that number of household in the construction 
area is approximately equal to 130 . The participants included the people who live in the Phuttabucha community and nearby communities, private and public organizations, and all of the stakeholders. Table 1 summarizes the participants' opinions collected during the public hearing event. These opinions were gathered from 106 participants out of the total number of 142. It can be concluded from Table 1 that, participants mostly agreed with the project and the proposed mitigation system. The additional comments from the participants included: (1) the mitigation system is required in the area immediately, (2) the maintenance plan of the mitigation system and recreation area should be implemented, and (3) the communities require to involve in the construction inspection.

Table 1. Summaries from the public hearing events.

\begin{tabular}{|c|c|c|c|c|c|}
\hline \multirow[t]{2}{*}{ Items } & \multicolumn{5}{|c|}{$\begin{array}{l}\text { Percentage of participant (\%) } \\
\text { (5 is strongly agree) }\end{array}$} \\
\hline & 5 & 4 & 3 & 2 & 1 \\
\hline 1. Project objectives & 19.81 & 62.26 & 16.04 & $\begin{array}{l}1.8 \\
9\end{array}$ & 0.00 \\
\hline 2. Project presentation & 17.93 & 62.26 & 16.98 & $\begin{array}{l}2.8 \\
3\end{array}$ & 0.00 \\
\hline 3. Project outcomes and the designed mitigation system & 28.30 & 52.83 & 16.04 & $\begin{array}{l}1.8 \\
9\end{array}$ & 0.94 \\
\hline 4. Explanations on the public's queries and requirements & 12.26 & 66.04 & 18.87 & $\begin{array}{l}2.8 \\
3\end{array}$ & 0.00 \\
\hline 5. The project has direct impact to your communities & 25.47 & 56.60 & 15.10 & $\begin{array}{l}2.8 \\
3\end{array}$ & 0.00 \\
\hline
\end{tabular}

\section{SELECTED MITIGATION SYSTEM}

The discussions during the public hearing event and the internal meeting with municipality led to the selection of second alternative as the designed mitigation system. Although, construction cost of the $2^{\text {nd }}$ scheme is higher than the $1^{\text {st }}$ scheme, the reasons for choosing the $2^{\text {nd }}$ scheme for this project are listed below:

1. The selected system effectively mitigates the damages due to flooding and river erosion events.

2. The construction times of the $2^{\text {nd }}$ scheme is shorter than the $1^{\text {st }}$ scheme.

3. The $2^{\text {nd }}$ mitigation system required lesser construction space than the $1^{\text {st }}$ scheme; therefore, space for the recreation area of the $2^{\text {nd }}$ scheme is larger than the $1^{\text {st }}$ scheme.

\subsection{Design of the Selected Mitigation System}

Figs. 8-10 illustrate the selected mitigation system. The top level of sheet pile wall was designed based on the highest water level during the flooding season. The staircases were provided as the access to the slope face for inspection and maintenance during the dry season. As mentioned earlier, the rock gabion is used in this scheme to strengthening the slope face and protecting the slope face from erosion. Fig. 9 illustrates the ancient city walls lay behind the selected mitigation system. The pedestrian, bike lane, and the rest area were also provided for the communities as shown in Fig. 10. Moreover, the style of guardrails and facilities in this project were designed to be consistent with the ancient city walls and the existing structures. 


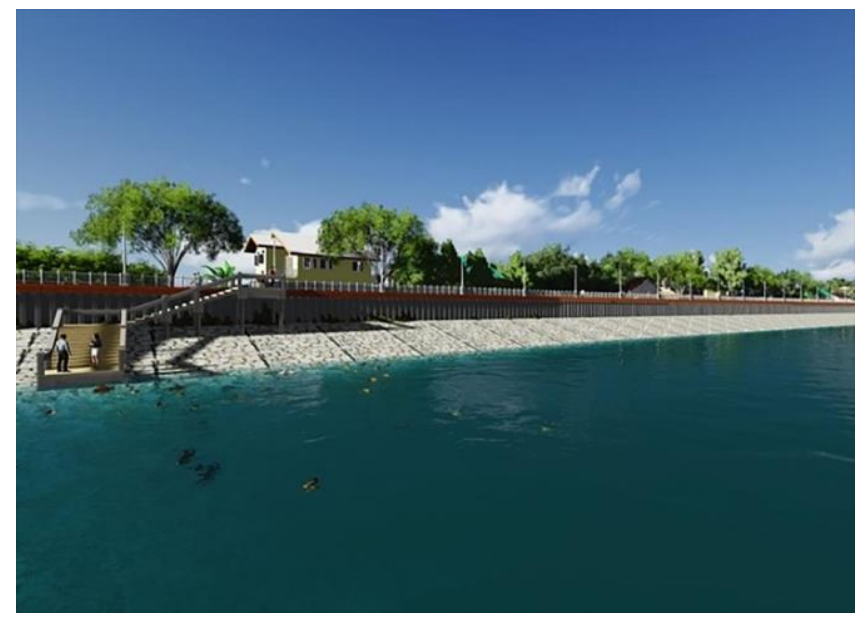

Fig. 8. Front view of the mitigation system.

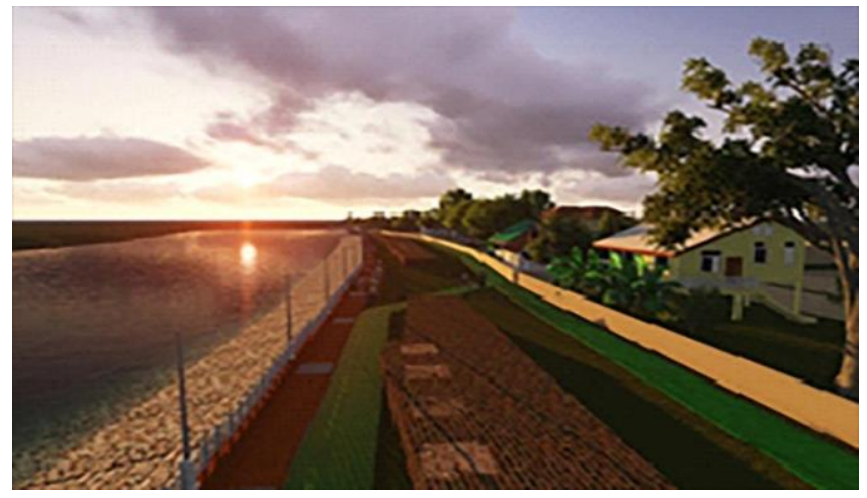

Fig. 9. Ancient city wall behind the sheet pile wall.

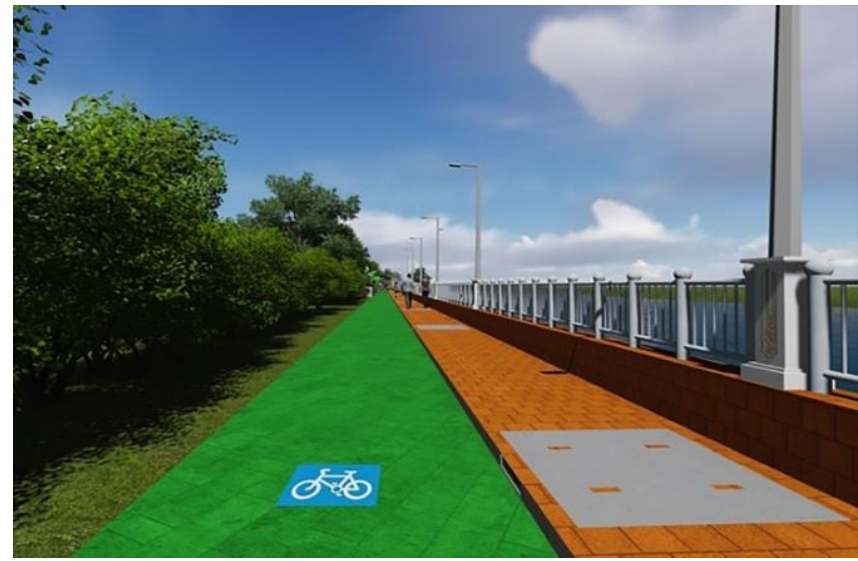

Fig. 10. Design for pedestrian and bike lane. 


\section{DISCUSSIONS AND CONCLUSIONS}

Phuttabucha community is located along the east riverbank of Nan river, northern district of Phitsanulok city, Thailand. The river characteristic in the upstream led to the strong river current flows toward the community. The Phitsanulok city is situated on both sides of the downstream riverbanks, south of the community, where many historical buildings were discovered. Accordingly, the flood protection and river erosion mitigation system is urgently required by the Phuttabucha community. However, due to the limitation of urban space, the mitigation system was also designed as the recreation area. In this project, the community was involved in the mitigation system selection through the public hearing event. The selected mitigation system was designed to serve two main purposes. Firstly, the system should mitigate the damages due to the river erosion and flooding events. Secondly, the mitigation system should serve as the recreation area to the communities. As a result, the mitigation system with the continuous sheet-pile wall was chosen for this project. This system requires the most appropriate spaces and times for construction. The pedestrian, bike lane, and rest area were also added to the designed mitigation system.

\section{REFERENCES}

Bergado, D. T. \& Soralump, S. (2003) Geosynthetic for Erosion Control and Preservation of Environmental. International Symposium and Short Course on Soil/Ground Improvement and Geosynthetics in Waste Containment Structures, AIT, Thailand.

Bergado, D. T., Anderson L. R., Miura N. \& Barasubramaniam, A. S. (1996) Soft Ground Improvement in Lowland and Other Environmental. ASCE Press, New York, USA.

Chuenchooklin, S. \& Pangnakorn, U. (2015) Flood Management Tool for Small Catchment in the Nan River Basin, Thailand. Journal of Applied Sciences Research, 11(21), 1-6.

Costache, R. (2014) Estimating Multiannual Average Runoff Depth in the Middle and Upper Sectors of Buzau River Basin. Geographia Technica, 9(2), 21-29.

Department of Public Works and Town \& Country Planning. (2006) Retaining Wall Design, [in Thai]. Design Guideline Report.

Ghaderi, Z., Puad M. S. A., \& Henderson, J. C. (2015) When Disaster Strikes: The Thai Floods of 2011 and Tourism Industry Response and Resilience. Asia Pacific Journal of Tourism Research, 20(4), 399-415.

Gomis, J. \& Turón, C. (2017) From Layout To Photoplan: Reflections On The“rePresentation"of Urban Planning. Geographia Technica, 12(1), 57-63.

Haidu, I., Ivan, K. (2016) The assessment of the impact induced by the increase of impervious areas on surface runoff. Case study the city of Cluj-Napoca, Romania. Carpathian Journal of Earth and Environmental Sciences, 11 (2), 331-337.

Haragushi, M., \& Lall, U. (2015) Flood risks and impacts: A case study of Thailand's floods in 2011 and research questions for supply chain decision making. International Journal of Disaster Risk Reduction, 14(3), 256-272.

Kabir, R., Suddhi-Dhamki, K., \& Fanf, Y. (2011) Disaster Risk Management: Post disaster needs assessment for sustainable recovery, Thailand floods 2011. UNDP Internal Report on DRMPDNA, UNPD, Bangkok.

Ministry of Finance, Royal Thai Government and The World Bank. (2012) Thailand Flooding 2554 Rapid Assessment for Resilient Recovery and Reconstruction Planning - Available from: http://www.undp.org/content/dam/thailand/docs/UNDP_RRR_THFloods.pdf. [Accessed March 2017].

Poaponsakorn, N., \& Meethom, P., (2013) Impact of the 2011 Floods, and Flood Management in Thailand. ERIA-DP-2013-34, ERIA Discussion Paper Series.

Phitsanulok Municipality, (2017) The Phitsanulok Municipality Population [in Thai]. - Available from: http://populace.phsmun.go.th. [Accessed March 2017]. 